\title{
昭和53年における「重要な燃料関係事項」（I ）
}

(Annual Fuel Reviews-1978)

（社）燃 料 協 会 編 集

1. 燃料一般

1.1 エネルギー需給の動向 ・日本エネルギー経済研究所…高 垣 節 夫…(471)

1.2 工業用燃料の動向

1.2 .1 電力用燃料 .電気事業連合会…中 島 信 行…(475)

1.2 .2 製鉄用燃料 .日本鉄鋼連盟…竹 下 栜 三 …(478)

1.2.3 内燃機燃料 次

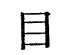
..日本石油㑣)...内堀 克 彦…(481)

2. 石 炭

2.1 石炭に関する研究……………………公害資源研究所…山 下 安 正…(487)

2.2 石炭鉱業の動向………………通産省資源エネルギ一宁…板 東 一 彦…(498)

2.3 採炭技術の動向（研究を含む）…………石炭技術研究所…山 村 礼次郎…( 502 )

2.4 コークス

2.4.1 コークス工業の動向…………………日本鋼管森…島 田 源 嗣…( 509 )

2.4 .2 コークスに関する研究………北海道工業開発試験所…吉 田 雄 次 …(525)

2.5 タール

2.5 .1 芳香族，タール工業の動向…………本芳香族工業会…島 津 豊治郎…( 529 )

2.5 .2 タールに関する研究………………名古屋工業大学…吉 田 高 年…(533)

2.6 炭素工業の動向（研究を含む）…………日本カーボン傐…寺 西 春 夫…(538)

3. 石 油

3.1 石油に関する研究 (性状, 構造, 化学)

.

東西燃料工業(㑣)...古 賀 雄 造…(541)

3.2 石油鉱業の動向. ..石油鉱業連盟…関 岡 正 弘…(545)

3.3 石油精製工業の動向. . 石油連盟 $\cdots$ 藤 沼 茂…(548)

3.4 石油精製に関する研究..... 日本石油(森…松 村 幾 敏…(554)

3.5 石油化学

3.5 .1 石油化学工業の動向……………………...揮㑣…平 川 芳 彦…(558)

3.5 .2 石油化学に関する研究…公害資源研究所…中山哲男・若林孟茂・斉藤昌弘…( 563 )

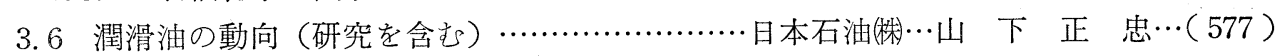

4. ガ ス

4.1 都市ガス需給と原料の動向………………日本瓦斯協会…猪 俣 誠…( 581 )

4.2 合成ガス製造の動向…………………..井東圧化学(㑣…金 丸 宗 昭…( 584 )

4.3 液化石油ガスの動向…………………日本 L P ガス協会…仲 村 泰 広…(590)

4.4 ガス化に関する研究………………早稲田大学理工学部…桜井初則・野呂隆…( 593 ) 会 報………(596) 